\title{
The Competency of State Elementary School Teachers in Mastering Digital Literation
}

\author{
Tatik Andayani $^{1 *}$, Edi Harapan ${ }^{2}$, Tahrun ${ }^{2}$ \\ ${ }^{1}$ SDN 19 Makarti Jaya \\ ${ }^{2}$ Universitas PGRI Palembang \\ *Corresponding author.Email: tatikandayani12@gmail.com
}

\begin{abstract}
This study aims to identify and describe the competence of Public Elementary School (SDN) 19 Makarti Jaya teachers in mastering digital literature, and the obstacles they face. The research method used was descriptive method. The research participants were teachers and principal at SDN Makarti Jaya in Banyuasin District of South Sumatera. The data were collected based on the interview with the respondents. Based on the research results, the teacher in planning learning at SDN 19 Makarti Jaya can be said to be good, where the teacher is able to plan learning according to the set curriculum, which refers to the 2013 curriculum (K-13) and has utilized technology look for sources of learning material to be delivered. However, for the 2020/2021 learning year, the lesson plan is designed to adapt to the state of the Covid-19 pandemic situation, because the learning planning process is directed through a group of teachers using the WhatsApp application. In the planning process carried out by teachers, first direction was given by the principal, as conveyed by the principal through interviews, namely that he had guided teachers in planning lessons by conveying information related to the lesson plans will be made based on a predetermined curriculum and update from the lesson plan that was made in the previous year.
\end{abstract}

Keywords: Competence, Teacher, Digital Literacy

\section{INTRODUCTION}

All aspects of human life cannot be separated from the influence of information technology, from the fields of economy, social communication, politics to education. Technology is a mandatory choice that must be applied in the world of education, not only in the context of education in general but also penetrating into education in particular, namely learning. As stated by Sidik that the integration of information technology in life today changes our relationship with information and knowledge including in the field of education [1]. It is common to find learning processes that integrate technology in it [2].

The literacy movement was developed by the Ministry of Education and Culture, thus there are several schools in Indonesia that implement literacy for their students.

Based on the description of the existing problems, and the importance of digital literacy at this time, especially the conditions of the Covid-19 pandemic, digital literacy is very necessary in the learning process delivered by the teacher, so that students do not miss their lessons, so that through digital literacy the learning process can be carried out as the usual. For this reason, seeing the reality in SDN 19 Makarti Jaya, researchers need to want to know more about teacher competence in mastering digital literacy through research with the title, "Competence of SD Negeri 19 Makarti Jaya Teachers in Mastering Digital Literacy."

Literacy encompasses more than just reading and writing; it also requires the ability to think critically about information presented in print, visual, multimedia, and auditory formats. In this 21 st century, this ability is known as information literacy. Ferguson [3] groups literacy into several types, namely Basic Literacy, Library Literacy, Media Literacy, Technology Literacy, and Visual Literacy. Chirstianti [4] describes the components of information literacy as basic Literacy comprises of the ability to listen, speak, read, write, and count. In basic literacy, the ability to listen, speak, read, write, and count (counting) is related to the analytical ability to take into account, based on personal knowledge, interpret information (perceiving), express information (communicating), explain information (drawing), and conclusions. This comprehensive and interrelated literacy enables a person to contribute to 
their society according to their competence and role as a global citizen. In the Indonesian context, these five skills need to begin with early age literacy which includes phonetics, alphabet, vocabulary, awareness and interpretation of print material (print awareness), and the ability to describe and retell (narrative skills).

Library Literacy means the advanced ability to optimize existing library literacy. This means understanding the existence of a library as an access to information. Basically, library comprehension is the ability to comprehend information while writing a text, doing research, working, or solving problems. Media literacy is the ability to grasp the intent of various types of media, such as print media, electronic media (radio media, television media), and digital media (internet media) as a tool to fulfill information about knowledge and provide positive perceptions in increasing knowledge [4].

Technology literacy is defined as proficiency in use and utilize new media such as the internet to access, disseminate, and communicate information effectively. ICT literacy interpreted also as media literacy that positions human beings who have the ability to understand, master, and utilize mass media content [5]. This technological Literacy is the ability to comprehend technology-related devices such as electronics, software, and technology-related ethics and etiquette. Next, be able to comprehend the technologies used to print, present, and use the internet In practice, there is also a knowledge of how to use machines (Computer Literacy), which involves turning the computer on and off, saving and manipulating records, and running software programs. Digital literacy is an advanced knowledge of information literacy and technology literacy that improves learning skills and desires through the critical and dignified use of visual and audio-visual resources. However, there are several manipulations and forms of entertainment that can be screened based on ethical considerations, and appropriateness [4].

\section{METHODS}

According to Djamarah, the research method is the method used by researchers in collecting research data [6]. She argues that a method is used to achieve predetermined goals. The analytical qualitative analysis approach was used in this study. The descriptive approach is a method for examining the current state of a group of people, an individual, a collection of circumstances, a system of thought, or a class of events [7]. According to Maleong [8], qualitative approaches are analysis techniques that generate descriptive evidence from people in the form of written or spoken phrases, as well as observable conduct. The resulting data are in the form of words, pictures and human behavior. Maleong [8] adds his opinion that research that has qualitative research is research that is carried out by observing, and is carried out in a natural setting or overall context, and the main data collection tool is research itself. Furthermore, suggests that the research method is the way to achieve goals. The research instrument used in this research was interview. The writers interviewed all teachers at the principal at SDN 19 Makarti Jaya of Banyuasin District of South Sumatera.

\section{RESULTS AND DISCUSSION}

Based on the results of the research, it can be analyzed as follows, the teacher in planning learning at SDN 19 Makarti Jaya can be said to be good, where the teacher is able to plan learning according to the established curriculum, which refers to the 2013 curriculum (K-13). It is known from the recognition of teachers through interviews that generally teachers as homeroom teachers at SD Negeri 19 Makarti Jaya plan in advance to prepare lesson plans. However, for the 2020/2021 learning year, the RPP is designed to adapt to the state of the Covid 19 pandemic situation, because the learning planning process is directed through a group of teachers using the WhatsApp application. In the planning process carried out by teachers first direction was given by the principal, as conveyed by the principal of SD Negeri 19 Makarti Jaya through interviews, namely that he had guided teachers in planning lessons by conveying information related to the lesson plans will be made based on a predetermined curriculum and update from the RPP that was made in the previous year.

The teacher in evaluating learning at SDN 19 Makarti Jaya can be said to be good, where the teacher is able to evaluate the learning that has been delivered. The results of the evaluation (assessment of student learning outcomes) are inputted into a list of values (legger) and grouped according to the value rating achieved by students, namely from the highest to the lowest in order to determine the ranking of student achievement from the learning results obtained. Based on the analysis of research data, supported by interview data are in the followings. The school principal has coached teachers in planning lessons by submitting information related to the lesson plans that will be made based on the predetermined curriculum and updating the lesson plans made in the previous year.

The principal has coached teachers in evaluating the results of the learning process that has been carried out, namely by conducting regular meetings so that teachers can provide an assessment as soon as possible to students after the learning process has ended, namely evaluating assessments both mid-semester, per semester and at the end of the learning process (end of semester assessment). 
The principal's effort to improve the ability of teachers in managing learning devices is by providing direction and guidance in preparing learning tools based on prota and process and solving the learning tools in detail which includes: details of effective weeks, time allocation, schedule for implementing learning activities based on face to face meetings. The principal's effort to improve the ability of teachers in managing students is by providing guidance and guidance so that teachers always condition students to be ready to learn, where teachers are advised to provide guidance and motivation to students to always study diligently.

Moreover, the principal's efforts to improve the ability of teachers to obtain educator certificates by advising teachers to always gain insight into teaching using the website, so that in the future it can be used as provisions for taking teacher competency examinations to pass and obtain an educator certificate Besides, the principal also added his explanation that the requirement to obtain an educator certificate is that teachers must have a minimum educational background of a Bachelor.

Next, the principal's effort to strengthen teachers' abilities to build and manage learning environments is by emphasizing the teacher's ability to deliver active, innovative, creative, effective, and enjoyable learning material. The principal's effort to improve the ability of teachers to overcome student learning difficulties is by providing guidance and guidance to teachers so that teachers can overcome student learning difficulties such as advising teachers to first evaluate students' difficulties in learning, and looking for factors that cause students it's having trouble

This is considered successful for teachers in providing guidance to students. The obstacle faced by teachers in mastering digital literacy is in planning the lesson plans, generally a matter of time is determined, where in planning to make RPP is given 1 (one) week by the principal, while the teacher's activities are very busy, both at school and at home. In addition, it is constrained by the existing network (signal), because the electricity often goes out, so that the use of digital literacy is disrupted. The problem of teachers in implementing learning, where before the teacher implements learning to use digital literacy there is a low signal problem, so it is slow loading using Android as a supporting medium in finding data sources for learning material to be delivered. The obstacle for teachers in evaluating learning outcomes by utilizing existing digital literacy facilities such as laptops, namely frequent power outages in the Makarti Jaya area, where this area is a water area in the Banyuasin Regency area. Nikolopoulou and Gialamas [9] group the challenges of using ICT in the learning process from three aspects, namely: lack of support, lack of confidence, and lack of equipment.

The problem with the teacher in providing guidance to students in this case is that the learning process is provided through an online system, including students who are less active in following guidance through the WhatsApp application. Since the teaching and learning process is primarily dictated by instructor influences, the teacher is a teaching aspect that plays a significant and main role. The teacher's role in the teaching and learning process is to convey subject matter to students through contact experiences. The success of the teacher in delivering the material is very dependent on the smoothness of communication interactions that have an effect on the message given by the teacher. This study is confirmed by the opinion of, where the teacher is a position or profession that requires special skills as a teacher. In short, utilizing ICT in learning is a mandate of the curriculum, where learning is carried out based on various learning resources. The teacher is no longer the only source of learning. In addition, based on the principles of learning, the use of information technology can increase the efficiency and effectiveness of learning. Therefore, it is very important for teachers to use technology in learning, starting from the planning, implementing and assessing learning outcome [10].

\section{CONCLUSION}

Based on the research findings, it can be concluded as follows. The competence of teachers in mastering digital literacy at SD Negeri 19 Makarti Jaya is considered good. The importance of teachers in mastering digital literacy has a positive impact on teachers' understanding and skills in using digital media, especially for educational media. This digital literacy program provides a good contribution for teachers, especially the education and training process for teachers to have digital literacy skills, so that some teachers can understand how to effectively utilize digital information media. It is known that teachers in planning lesson plans are considered good, where teachers often use digital literacy in finding data as a source of learning material to be delivered. The teacher makes the lesson plan is good, where the lesson plan is made updated from the previous lesson plan by utilizing digital literacy, so this method is considered practical and efficient to be used in delivering learning material. Teachers in carrying out learning are considered good, where before the teacher carries out learning to use existing digital literacy such as using android as a supporting medium in finding material data sources.

\section{ACKNOWLEDGMENT}

We would like to thank the Chancellor of the PGRI Palembang University, Postgraduate Director, Head of 
Education Management Study Program, Thesis Advisor and fellow students of Makarti Jaya Class who have helped us in the preparation of this journal.

\section{REFERENCES}

[1] Sidik, S. (2013). Dampak Undang-Undang Informasi dan Transaksi Elektronik (UU ITE) terhadap Perubahan Hukum dan Sosial dalam Masyarakat. Jurnal Ilmiah Widya, 4(2).

[2] Helaluddin. (2019). Peningkatan Kemampuan Literasi Teknologi dalam Upaya Mengembangkan Inovasi Pendidikan di Perguruan Tinggai, PENDAIS, 1 (1). 44-55.

[3] Ferguson, B. (2005). Information Literacy: A Primer for Teachers, Librarians, and other Informed People. Utah, USA: Bibliotech.us.

[4] Christianti, M. (2013). Reading and Beginning Writing For Early Childhood. Journal of Education, 2 (2). Yogyakarta State University.

[5] Syarifuddin. (2014). Literasi Teknologi Informasi dan Komunikasi. Jurnal Penelitian Komunikasi, 17(2), 153-164.

[6] Djamarah, Syaeful Bahri. (2010). Research Methods and Statistics. Jakarta: Rajawali Press. [2]

[7] Prastowo, A. (2011). Qualitative Research: Learning Design Techniques. Jogjakarta: Diva Press.

[8] Moleong, L. (2011). Qualitative Research Methodology. Bandung: Youth Rosdakarya.

[9] Nikolopoulou, K. and Gialamas, V. (2016). "Barriers to ICT use in high schools: Greek teachers' perceptions", Journal of Computers in Education, Vol. 3 No. 1, pp. 59-75

[10] Bastudin. (2020). Hambatan Utama Penggunaan TIK dalam Pembelajaran dan Strategi Mengatasinnya. Online (available at: http://lpmpsumsel.kemdikbud.go.id/site/blog/2020/ 06/17/hambatan-utama-penggunaan-tik-dalampembelajaran-dan-strategi-mengatasinya/) 